Research Article

\title{
Trade policy and green growth
}

\author{
Evi Susanti Tasri ${ }^{* a}$
}

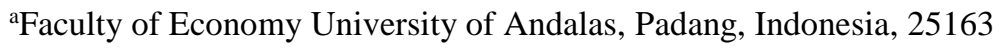

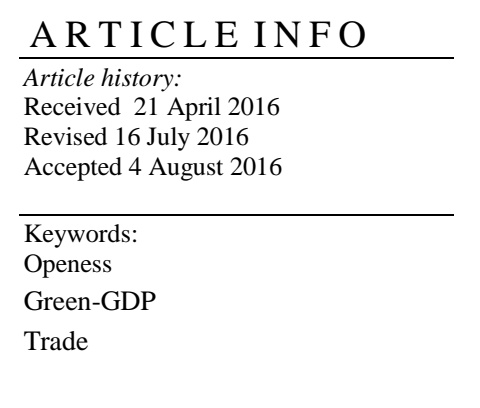

\begin{abstract}
A B S T R A C T
Nowadays, Limited Natural resources and population Growth demanded a fundamental change in economic policy. This paper tried to assess the link between economic growth especially green growth and Trade policy in the form of economic openness. The Study conducted by using survey literature and empiric. The outcomes of theoretical study of literature and empirical finding using panel data showed a significant effect of openness trade policy on Green GDP growth of countries.
\end{abstract}

(C)2017

\section{INTRODUCTION}

Economic development today requires a change in policy and behaviour in economic activities (human evolution). It is because of the limited natural resources needed, coupled with population growth, so that the changes in policy and behaviour is expected to create a steady state between the resources and the environment for long-term(Bran \&Ioan, 2012). This raises an effort to protect the resources and limit usage ratio.

Currently, an indicator of economic development is not accompanied by information about the waning value of natural resources (depletion) and the damages and environmental contamination(degradation). Then, a concept that accommodates those matter is needed. Green economy approach is a concept that has taken into account the impact of depletion and degradation that is a model of economic development approach where is no longer rely on economic development based on the exploitation of natural resources and environmental over load.

Green economy is a model of economic development based on knowledge of the ecological and economic green which aims to answer the interdependence between the economy and the ecosystem as well asthe negative impact of economic assets, including climate change and global warming. The
Factors are important in the economic development; (1) population, (2) natural resources,(3) production industry, agricultural production, and(4) pollution. Pointland 2 above provide a positive impact in the economic system that supports the growthandpoint 3,4 and 5 have a negative impact on the development such as pollution, resource shortages and increased poverty.

Meanwhile, according to the United Nation at General Assembly in1985"Development mean the comprehensive process of economy, social, culture and politics in order to further improve the standard of living among the population and the individual". Pollution in a closed economy has the opposite effect, reducing the productivity of natural resources and pushed up prices of goods produced in this sector.

Related to these problems, it is necessary for the basic model of stability in economic growth by combining the steady state model of the development policy to limit the ecological limitations (Bran \& Ioan, 2012). Green economic growth is also needed to address climate change, because of the economic growth resulting in environmental impacts like global warming (winter, 1999). This is also supported by Kuznets statement stating that GNP is not the most important thing in determining the size of a country because of economic growth should 
describe quantity and quality between the short run and the long run.

On the other hand, it is known that the globalization of capital lead to bad consequences such as loss of habitat and species (Tucker \& Gring, 2001). The marginal benefit of environmental quality associated with the addition or reduction of pollution, where it is necessary requirement in the achievement of social optimum, as discovered by Saito and Yakita (2008) in the case of the Japanese state. In addition, the next problem is that if the cost of environmental policy shifted to consumers (in the form of higher prices), the level of consumer prices will rise, this condition implies a reduction in real returns factor (Goulder, 2013). Therefore there is market failure. For that we need a comprehensive model in setting a policy, so that the negative effects of the development process can be reduced. So that the costs inherent in the clean economic development is much lower given the negative externalities on the environment, economy and politics.

\section{DISCUSSION}

The following section will try to examine the role of trade policy, particularly the policy of economic openness in relation to the concept of green economic growth. Analysis continued with the study of how the development of the theory of growth, until eventually evolve into a model of green economy growth.

\subsection{Trade Policy; Economics Openness}

The research of Green Growth has been widely used a new indicator that is economic openness indicator in relation to the environment (Wang, 2011). Furthermore, (Talberth \& Boharas, 2006), building a model of Green GDP growth and Model of Gap (between GDP and Green GDP). The effect of economic openness tested on both growth models and founded a negative correlation with growth models Green GDP and a positive correlation with the model Gap. While (Wang, 2011) examined the effects of openness on Comparable Green GDP model, a variant of Solow growth model, at the provincial level in China. Found that there is a nonlinear relationship between the Green GDP and Openness.

The economic openness in relation to GDP growth has had considerable theoretical support (Talberth and Boharas, 2006). Empirical studies describe openness through a variety of approaches to describe the various forms and conduct of trade policy. As a consequence, it created a lot of measure of openness and trade policies.

The Variety of measure of openness caused by the difficulty of finding the relationship between economic growth and a condition of free trade. Winters, McCulloch, and McKay (2004) mentions there are three sources of difficulty. First, measure the position of the trade is a difficult job because of trade policy are diverse. Second, the direction of causality between openness and growth are difficult to establish. And third, the interaction of openness policy with other trade policies must be considered when determining the effect of openness on economic growth. Trade policy involving many instruments such as tariffs, quotas, protection, non-tariff impediments, the amount of government procurement, and trade policy making techniques and methods of measurement of openness varies. Plus the problem of availability and quality of data on each instrument (Lane, 2007).

Some experts try to classify the measure of openness. H Lane collect 30 different measure of trade openness and try to review it based on the classification made by Rose (2002). The classification made Rose is dividing the measure of trade openness and policy into six groups, namely; 1 . Trade ratios, 2. Adjusted trade flows, 3. Price-based, 4. Tariffs, 5. Nontariff barriers and 6. Composite Indices.

Of the many existing methods of measurement, the trade ratio categories is the most popular method and most widely used, often calculated as (Exports + Imports) / GDP (Lane, 2007).

Openness through international trade will support a country to be more focus on the production of goods which have a comparative advantage and import goods considered to be more expensive if produced locally. In general openness is understood as the extent ofbarriers trade between the local communities of a country and a foreign country.

Many studies support the idea of a positive relationship between trade openness and economic growth. Strong support can be found within the framework of the growth model that shows a direct positive correlation between growth with a selected policy trade regime more freely as proposed by Dorwick (1994) in which he stated that in the past ten years showed a 
pattern consistent enough for the positive relationship between growth and trade openness. The relationship between economic openness and growth is also found in empirical studies that rely on data sets larger, up to 105 countries, (Talberth \& Boharas, 2006).

Along with the policy of economic integration at the global level in the form of economic openness and free trade, found on some theoretical and empirical studies of the relationship between income inequality, environmental degradation, poor working conditions and the loss of local culture with economic openness. Research conducted Ozay and Tavakoli (2003); Baten and Fraunholz (2004); Ghose (2004); Marjit et al. (2004) showed evidence of a significant correlation between openness to the greater the income gap (Talberth \& Boharas, 2006). In line with the above, Karimi (1995) revealed that in the last few years, prior to 1995, reported a decline in the poverty rate in Indonesia, but the unequal distribution of income is thought to be the main cause of this reduction in the proportion of poor people. This is where the role of green GDP, where the quality of the environment play a role in determining the distribution of income between countries and income level.

Green economic cannot be implemented without changing the incentive structure of the economy. Low yields in the green economy is the biggest obstacle to success. Essential elements for changing the incentive structure is the fiscal policies. Energy price reform is also essential for the green economy.

\subsection{Green Economy and Pollution}

The phenomenon of economic openness requires the free flow of goods, services and investment between the countries. The real impact of trade liberalization on the environment, in this case in developing countries, is feared to be a "pollution haven" for developed countries. Because capital inflows / investment from developed countries, in order to avoid relatively strigent environmental requirements in their country, are dilemma for developing countries. whether the economic or the environmental should take precedence.

A number of studies examining the relationship between economic growth and environmental quality like a social welfare function, damage due to pollution, cost reduction and productivity of capital / investment (John et al., 1995). And a number of empirical studies on the relationship of pollution and per capita income (Cole et al., 1997).

Currently, still not much study on the relationship between economic growth and pollution, especially with regard to "pollution haven". Kellenberg (2009); Brunnermeier and Levinson (2004) states that the effects of "pollution haven" is one of the most contentious issues in the context of international trade, namely the empirical validity of foreign investment on the environment. Taylor (2004) makes the argument that the employment / labor has a strong relationship with the environment. Cole and Elliott (2003) asserts that there is a significant positive correlation between production capital and the level of environmental pollution. While Antweiler et al. (2001) and Liddle (2001) argues that international trade may be good for the environment, because by relying on technology transfer through foreign investment to reduce pollution.

From the literature, the relationship of economic growth and environmental pollution caused by international trade, can be analyzed by the method pollution haven hypothesis (PHH). This method can be used for the implementation of environmental policy (Birdsall et al., 1993).

\subsection{The development of the theory of growth}

The development of economic theory in general and in particular the theory of growth can not be separated from the circumstances of its time demanding the economists to develop a theory that is more relevant to that period. For example, after the great depression around the 1930s, many economists had questioned the laissez faire economics. Policies taken by the government based on the existing economic theory at that time was not able to restrain the rate of unemployment, decline in production and a decline in stock prices.

The development of the theory of growth, as well as other social science theories influenced by the circumstances at that period. Economic theory is required to able to solve the existing problems. Robert J. Barro in his book Growth Economics said that economic growth is the main focus of the current macroeconomic studies. Barro stated that if we want to know the difference in the living standards of the countries which is very large, it must be understood why these countries experienced a sharp divergence in long-term growth rate. 
Small differences in the rate of growth if it accumulates will give a big effect on the standard of living (Barro and Sala-i-Martin, 1995).

The history of economic growth theory according to Barro starts from Ramsey classic article, A Mathematical Theory of Saving that called by Keynes as an outstanding work. How much to save by a country from its income is the question at the beginning of his article (Ramsey, 1928). Ramsey models is modified to better suit the neoclassical growth model. In 1928, Charles W. Cobb and Paul H. Douglas published a theory known as the Cobb-Douglas Production Function (Cobb \& Douglas, 1928).

John Maynard Keynes (1921), wrote a work, A Treatise on Probability. Keynes saw the need for state to become a counterweight in order to keep the growth of capital, such as the time it reaches the saturation point will not burden the living standard of the current generation (Keynes, 1936).

Keynes thought that much influenced by Alfred Marshall, Keynes argued that the government needs to intervene in order to maintained sustainable market balance. Development of Keynes's General Theory by Keynesian, especially in the financial sector, shows that the real view of Keynes is differ from neoclassical economists.

In the year 1939, Sir Henry Roy Forbes Harrod issued a growth model known as the Harrod-Domar growth model. In his article, Harrod suggests three propositions that Harrod (Harrod, 1939); (1) community income level is the most important thing in determining supplies; (2) savings; (3) the rate ofincrease in the community income is important to determine demand deposits and (4) the demand is equal to an offer.

Meanwhile, according to Solow the extraordinary characteristics of Harrod-Domar model is consistent with the long-term economic study tools for short-term, but Solow also showed some weaknesses of Harrod-Domar model. Harrod-Domar model is causing excitement neoclassical economists discussion panel, which then lead to the emergence of a growth model that is now widely used in the analysis of macro-economics, Solow-Swan Model of Growth.

In the year 1956, Solow published his work A Contribution to the Theory of Economic Growth in the February issue of the Quarterly Journal of Economics. In the same year Trefoe
Swan also publish his work Economic Growth and Capital Accumulation. This Growth models are known as the Solow Swan growth model used widely in the literature of growth. Solow bring the production function, which by Harrod processed with Keynesian analysis, back to the neoclassical model. Furthermore, Solow said that the developed model is the model of full employment economic. In general, the Solow model contains three variables, namely, technological change, capital and labor.

Currently, economists try to develop the Solow model to include the environmental variable. A variant of the Solow model developed by (Brock and Taylor, 2005), known as the Green Solow model, describes the influence of technological developments on the value of the pollutant, which is assumed constant ratio of workers and capital. The same was done by Saito and Yakita (2008) tried to analyze optimal policy of government revenues allocation, i.e. taxes, and spending on environmental sustainability using Solow growth model.

Nicholas Kaldor is an economist of Cambridge, in 1957, Kaldor published an essay, A Model of Economic Growth, in the Economic Journal using a dynamic approach Harrodian and Keynesian analysis techniques.

In 1961, Nicholas Kaldor stated what is now known as "stylized" fact. Kaldor use this fact to summarize the analysis of economists about the process of economic growth and use it as a framework of thinking for future research. Jones and Romer (2009) restates the fact Kaldor stylized as follows:

1. worker productivity grew at a steady rate (sustained)

2. Physical Capital per worker is growing at a sustained rate

3. The level of real interest rate or rate of return on capital has stabilized

4. The ratio of physical capital to labor is also stable

5. Capital and workers get the same division of the national income.

6. Among fast-growing countries, there are variations that can be appreciated in its growth rate, in the range between 2 to 5 percent.

It is important to note that Kaldor himselves have high expectations of the neoclassical growth model that was originally proposed by Solow and Swan. The model can explain the five facts Kaldor. This is one of the great 
achievements of the neoclassical growth theory, Jones and Romer (2009).

Furthermore, Jones and Romer formulated the Kaldor fact in a form more appropriate to current conditions. They put forward the facts as follows:

1. The increase in market reach. Increased flow of goods, ideas, financial and people through globalization and urbanization have increased market coverage for all workers and consumers

2. Acceleration of Growth. In thousands of years, an accelerated growth of population and GDP per capita increase rapidly in the last hundred years.

3. Variations in the rate of growth of modern. Variations in GDP per capita growth rate increases with the distance of forefront technology.

4. Revenue great and the difference TFP (Total Factor Productivity). The difference in the measured input explain large differences in GDP per capita.

5. Increased human capital per worker. Human capital per worker increased dramatically throughout the world.

6. Long-term stability relative wages. An increasing number of human capital relative to labor takterampil not in accordance with the continuous decline in relative prices.

\section{4. The Seed of Development of Green Economic Theory}

In general, the economic theory that flourish after the second world war is within the framework of the capitalist economic system, with the exception of the communist countries until the collapse of the soviet. Previously, the economic system of sharia (Islamic economics) also abandoned after the collapse of the Ottoman Caliphate in the first world war. The development of capitalism which was originally an economic system metamorphosed into a sociocultural system thanks to the contributions of social scientists thought to an inqury into the nature and causes of the Wealth of Nations posed by Adam Smith.

Smith introduced the theory of capital accumulation, liberalization of the markets and the division of labor in building the prosperity of a nation, while Maltus oppose this new model of prosperity (Skousen, 2001). In his study, Maltus included environment elemet into economic models. Maltus held a view that the growth of food production at some point is no longer able to support the growth of the population. This view can be seen as a form of concern. Concerns about the environmental carrying capacity is a seedof the green economy.

Other seed of the green economy is on the development of distribution theory that is driven by the uneven distribution of wealth. Unequal distribution of income is also the topic of the Kuznets curve which is popularly used in viewing economic relations with the environment. It is noteworthy that during this period, known as the classical period, the economy is not a stand-alone discipline. It can be seen from the titlesof economists publication that use the term "Political Economic".Other result of eropean social revolution in 1848 was the growth of socialist and Marxist economics that opposite the capitalist economy.

Barro and Sala-i-Martin (1995) says that the idea of the growth significance has been in the thinking of economists for a long time, thinking about the green economy has also long existed, even Adam Smith also questioned the prosperity gap between nations in Europe. (Kennet \& Heinemann, 2006) states that the green economy as a new school of thought which began to show its shape and set sail to explore the destination, roots and philosophical foundations. According Kennet, green economy is based on the philosophy of "How to set upeconomy for nature as usual, instead of setting the environment for business as usual".

Furthermore, Dobson (2000) laid the foundation and scope of philosophical ideology in the book Green Political Thought. He states that "ideology ecologism distinguished precisely because it argued for consumption less, and this is what marks the difference of environmentalism green: we can do more with less" (Kennet \& Heinemann, 2006). And several other writers approach this green thinking from their respective disciplines or sub-disciplines.

UNEP explained that the green economy is an economic model or concept in economic development based on knowledge of ecological economics, while Margulis widely and openly definethe green economy as any economic theory that considered economic as a component of the ecosystem in which it is located. Therefore, Sudarsono Soedomo tried to explain the concept of a green economy through socio-cultural and technological approach in his paper (Soedomo, 2010). 
Soedomo cites Cato (2006) which explains the green economy as shown below:

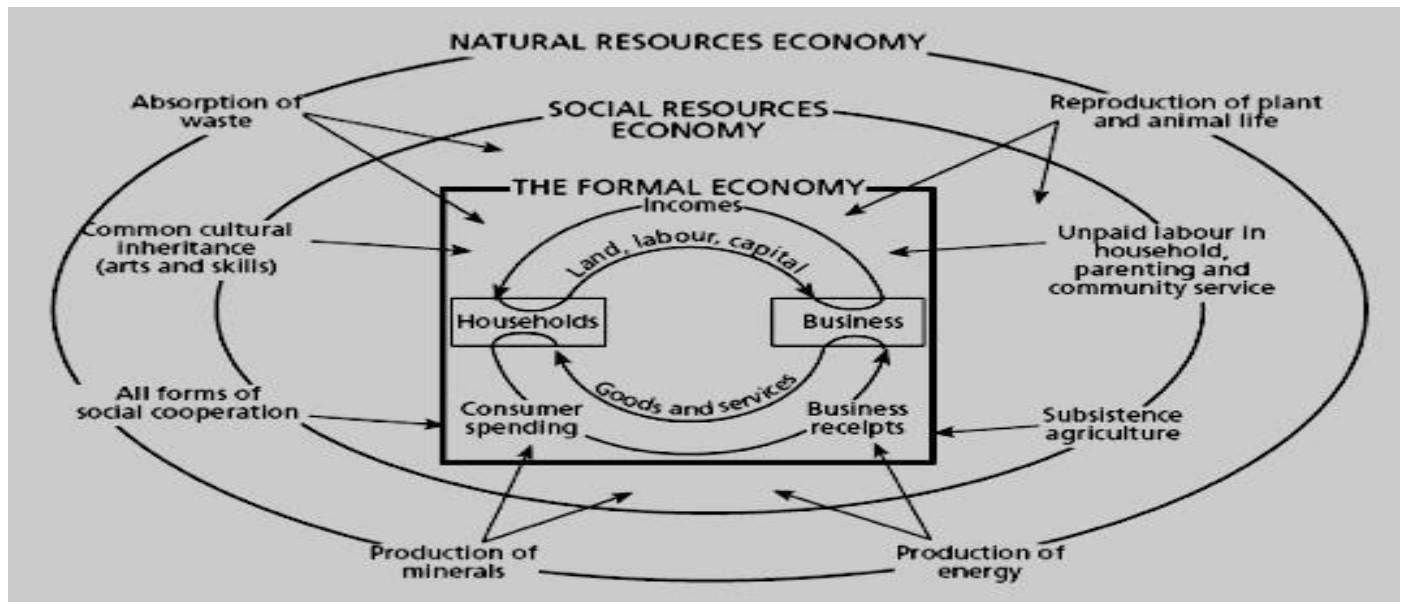

Figure 1. Expansion of economic calculation is out of bounds of conventional economic cycle (Cato (2009) cites E. Hutchinson, M. Mellor and W. Olsen)

Formal economy or mainstream economics ignores the fabric of society and the environment feature, in which households and business takes place, in its calculations. For several hundred years the mainstream economic view nature as anabundant free source and can be drained for accumulating capital. Environmentis is used arbitrarily despite the obvious weak environmental carrying capacity.

Goldsmith (2005) showed that environmental economics tries to adjust neoliberal economic and environmental costs. However, this can only work if the adjustments made in small scale, but if adjustments are made for the entire feature of environment, then obviously rewriting the discipline of economics to incorporate the environment into the calculation is needed (Kennet \& Heinemann, 2006).

Environmentalism, as Dobson pointed, adjust the neo liberal economy in the form of sustainable development of economic (Dobson, 2000). Park (2013) states that the green economy is a sub-pillars of sustainable development. According to the Kennet and Heinemann (2006), in line with the philosophy ecologism, rewriting the discipline of economics is the duty of the green economy.

\subsection{Comparison of Green Economy and Conventional Economy}

There are some differences between the green economy and mainstream economic observed by Cato. The following are excerpts of Cato's opinion about some of the things that distinguish green economics from conventional/mainstream economics (Cato, 2009):

1. Science green economy is inherently concerned with social justice. For mainstream economists, welfare economics is simply an additional, small pieces which are barelytouched. For a green economist, equity and justice is the heart that is given attention exceeds attention to efficiency.

2. Science of green economy grew from environmentalists and green politicians because of their interests on the matter. Science of green economy grows from the bottom up and from them who build a sustainable economy in practice rather than in abstract theory.

3. The science of green economy is not, until now, an academic discipline with a major in university. Here Cato stated that the university itself has been caught in a globalized economic system. So the offered curriculum is the curriculum that supports the global economy.

4. Science of green economy requires a greater understanding about people, their relationships, and how they act and motivated. The need to consider not only physical needs but also psychological and spiritual needs.

5. Science of green economy widens the circle of concern beyond the human species for the sake of the planet as a whole with all the ecological and diverse species.

6. conventional economics focuses almost solely on quantity, while adherents of green 
economics is more concerned with the quality of human life.

Meanwhile, (Karimi, 2012) made a comparison between conventional Economy Green Economy in the perspective of ecological economics as follows:

Table 1. Comparison of Conventional Economic and Green Economic (Eco-Economy)

\begin{tabular}{|c|c|}
\hline Conventioal Economy & Green Economic (Eco-Economy) \\
\hline $\begin{array}{l}\text { - Lead by market force. } \\
\text { - Not sustainable: maximum profit } \\
\text { regardless of the ecosystem. } \\
\text { - Consuming many of fossil fuels. } \\
\text { - Damaging the environment and climate. } \\
\text { - carbon-based car industry. } \\
\text { - Pollution, noise, and traffic jam. } \\
\text { - Decreasing with reduction in reserves of } \\
\text { natural resources. }\end{array}$ & $\begin{array}{l}\text { - Respect the principles of ecology. } \\
\text { - Sustainable. } \\
\text { - Identify ecosystem services. } \\
\text { - Rely on renewable resources. } \\
\text { - Minimize pollution. } \\
\text { - hydrogen-based car industry. } \\
\text { - Develop a bicycle friendly city. }\end{array}$ \\
\hline
\end{tabular}

Source: (Karimi, 2012)

More

Park, members of the OECD, concluded some differences betweena green economy, as subin the table below: specifically, pillars of sustainable development, and green growth

summarized

Table 1. Comparison of Green Economy and Green Growth

\begin{tabular}{|c|c|c|}
\hline Criteria & $\begin{array}{c}\text { Green Economy as subpillar of } \\
\text { sustainable economy }\end{array}$ & Green Growth \\
\hline Core values & $\begin{array}{l}\text { Justice between people and } \\
\text { between generations A relatively } \\
\text { longer period of growth (in quality) } \\
\text { More extensive and comprehensive }\end{array}$ & $\begin{array}{c}\text { Not sacrificing welfare } \\
\text { Direct growth (in quantity) }\end{array}$ \\
\hline $\begin{array}{l}\text { Perspective } \\
\text { on resource }\end{array}$ & $\begin{array}{l}\text { Human resource development with } \\
\text { the approach of anthropogenic, } \\
\text { human nature }\end{array}$ & $\begin{array}{l}\text { efficient exploration of natural resources for } \\
\text { sustainable growth. Find a new growth engine } \\
\text { and opportunities of environmental conditions }\end{array}$ \\
\hline Policy Tools & $\begin{array}{l}\text { Applying balanced approach to } \\
\text { long-term development }\end{array}$ & $\begin{array}{l}\text { Give top priority to fiscal and rules such as tax } \\
\text { and competition policy } \\
\text { Provide incentives for efficient use of sources } \\
\text { Giving (value) price on natural resources } \\
\text { Make the pollutant more expensive }\end{array}$ \\
\hline $\begin{array}{l}\text { Policy } \\
\text { Framework }\end{array}$ & $\begin{array}{c}\text { Three pillars (social, } \\
\text { economic and environmental) } \\
\text { UNEP Green New Deal } \\
\text { IWI UN and the World } \\
\text { Bank WAVE }\end{array}$ & $\begin{array}{l}\text { mainstream economy, fiscal policy and the budget } \\
\text { (for the environment). } \\
\text { Green Growth Indicator }\end{array}$ \\
\hline
\end{tabular}

Source: Jeongwon Park (2013)

\subsection{Growth Green Economic}

Thus, it is clear that the development of a green economy are outside the mainstream. If the concept of gree economic widely accepted then the mainstream world economy will shift. For example, a socialism economy have shifted the mainstream in the concept of distribution of wealth, while the environment / ecological economy, in particular the concept of nonrenewable resource) and limits to growth, shift the mainstream towards the concept of sustainability (sustainable).

A few decades back, the world preoccupied with sustainable development, especially in the field of economic development. Mathew call it 
naturalizing capitalism, a next major transformation of capitalism, in which a set of new policies that reflect a pure shift from "business as usual", eg carbon emission reduction policies (Mathews, 2011).

Industrial capitalism which Mathews calls the first major transformation of capitalism cause global ecological no longer have carrying capacity for growth. This led to the concept of green economy that became pillars of sustainable development (Mathews, 2011). Furthermore, Park (2013) mentioned that green growth was brought in 2009 by policy makers and practitioners of international organizations. The concept originally borrowed from Green New Deal of the United Nations Environment Programme (UNEP), and the term green growth was first used in 2005 in the 5th conference of ministers in ESCAP (Economic and Social Commission for Asia and the Pacific) to discuss Environment and Development in Asia and the Pacific having previously referred to in Davos Forum in 2000 and in The Economist. The main reason for the emergence of green growth concept are disappointing results and unexpected difficulties in the concept of sustainable development which has failed to promote the tangible environmental principles and focus policy frameworks that internationally accepted.

Economic growth has been proposed as an alternative and simultaneously to foster the dynamics of global environmental organizations and give new energy to the world economy, Park (2013). In April 2013, the global organization comprised of the Global Green Growth Institute (GGGI), Organisation for Economic Cooperation and Development (OECD), United Nations Environment Programme (UNEP), and the World Bank published a paper, The Green Growth Knowledge Platform (GGKP), whose program was officially launched in January 2012 in Mexico City which is financed by the Swiss Confederation. Green Growth Knowledge Framework provides the tools to develop and implement economic growth sustainable development.

\section{THE FINDINGS OF THEORITICAL AND EMPIRICAL STUDIES}

The following section is a review of theoretical and empirical studies conducted in the case of trade policy in the form of economic openness in relation to the growth of the green economy in several countries at different times.

\subsection{Several Green Growth Research}

The development of "green economy" to "green economic" development can not be separated from the study "Green Growth". Awareness of physical capital and the reduction in the environment carrying capacity create shifting consumer demand from maximum utility towards optimum utility that takes into account environmental sustainability. Report written by Meadows in 1972 for the Club of Rome, Limits to Growth, reviving discussion of environmental carrying capacity, which raised by Maltus nearly two hundred years ago, in this era of the modern economy.

Economists are so excited to study in order to dismantle economic theories and test it with the data, in order to prove the need to put a price of environment value in economic calculation. Aspects of environmental impurities, pollutants is a theme that has been accepted and become a global policy, such as pollutants or pollutants allowance trading or trade emissions. The term ecological economist invoked to distinguish mainstream economists (environmental economist) and green economists.

One popular theory which used by ecologists in conducting research is the Environmental Kuznets Curve (EKC) adopted from Kuznets curve (KC). Kuznets curve is a curve made by Simon Kuznets (1955) to explain the relationship of income per capita (the $\mathrm{x}$ axis) and inequality (y-axis). Kuznets said, initially the increase in income per capita will lead to increased inequality in income up to a certain point (turning point), then the increase in revenue will be lower the levels of economic inequality (Yandle, Vijayaraghavan, and Bhattarai, 2002).

Kuznets curve is much criticized for this curve does not provide a general overview of revenueInequality relation and does not apply in many countries. Several studies prove that the curve is not applicable to Latin American countries or the countries of East Asia. Field(2001) in his paper proves that Simon Kuznets hypothesis was rejected.

Environmental Kuznets Curve (EKC) is widely used in studies of the relationship between the economy with the environment. EKC is a curve that was adopted from the inverted U-shape of kuznets curve to explain the relationship between the environment and 
revenue. EKC concept emerged in the research report by Grossman and Krueger (1991) on the environmental impact of North American free trade agreement by the National Bureau of Economic Research. EKC term was later popularized in the World Bank Development Report 1992 (Stern, 2004).

Similarly withthe controversial $\mathrm{KC}$ (Kuznetz Curve), the validity of the EKC as "standard curve" of ecological economic is an interesting research theme. Yandle in his paper, The Environmental Kuznets Curve: A Primer, concluded that none of the EKC relationship that is suitable for all pollutants in all places and times. In some cases, EKC is the best approach to the relationship between environmental change and growth of revenue, and in some cases not. For local air pollution (particulate air impurities), the relationship between income and pollutants like U-inverted curve.

On the other hand, there is no evidence to support the hypothesis EKC for gases such as carbon dioxide. Also indicated that improving the quality of the environment in line with the revenue growth is not automatic, but depends on the policies and institutions. GDP growth created the conditions in which the environmental quality improvement is needed and resources can be allocated to improving the quality of the environment (Yandle et al., 2002).

David Stern also provide evidence with theoretical criticism and econometric data from developing countries, that the EKC very weak statistical foundation. Stern stated that the new generation of efficient frontier model of decomposition and will probably lead to the disappearance of the classic EKC.

Other researchers have also tried to explain the relationship between the Solow-Swan growth model with EKC. Brock ad Taylor for example, try to explain their arguments about close relationship between modern macroeconomic core model, Solow-Swan model, with a curve which is a standard curve environmental economics, Environmental Kuznetz Curve (EKC). They explained that by modifying the Solow model to incorporate technological progress into pollution reduction concluded that EKC is a derivative product that needs to be out of convergence to a Sustainable Growth (Brock and Taylor, 2015).

Based on the model talberth and bahora, that include trade openness in assessing economic growth, where economic growth is analyzed by introducing the concept of green GDP.It was found that economic openness has negatively significant influence to the formation of the green GDP value both in developing countries and in developed countries. Analysis also showed that on GDP GAP model, which represents the difference between the value of GDP conventional and green GDP , is found that economic openness variable has a significant influence in determining the value of GAP GDP this case is found in the group of developed countries or groups of developing countries, (Tasri, 2015)

Saito and Yakita (2008) investigated a Green Solow model to gain optimal environmental policy that is optimal allocation of government budget for productive capital and reduction of pollution. Concluded; after long-term optimum is reached, environmental quality optimally supported by policy of environment investment, the relationship of income and pollution has a $\mathrm{V}$-shape oblique-reverse, so EKC may reflect the environmental and development policies.

\section{CONCLUTIONS}

Through the study of literature and empirical findings in previous studies, it can be concluded that Trade Policy in the form of economic openness is an economic policy that need to be examined its influence in economic growth. Economic growth in the development of the growth theory has begun to shift from the conventional economic model towards a green economy concept. The concept of green economy that is growing today is no longer just a discourse, but it is a necessity and evaluation of policies in achieving economic sustainability.

Several studies have found a significant relationship of the green economic growth with a trade policy which in this case is the economic openness. There is a significant negative correlation between economic openness and green economic growth on empirical findings, both for developing countries and developed countries group. So, in doing the trade policies of each country should start paying attention to the negative impact caused by the policy on the environment or green growth. This is very important because the growth of the green economy is able to determine how a country is able to achieve sustainable economic development 


\section{REFERENCES}

Antweiler, W., B. R. Copeland and M. S. Taylor (2001): "Is Free Trade Good for the Environment?", American Economic Review 91(4), 877 - 908.

Barro, R. J., \& Sala-i-Martin, X. (1995). Economic Growth. New York: McGraw HIll Inc.

Bran, F., and Ioan, I. (2012). Sustainable Development Conditions for Survival of The Planet, Agro Food and Rural Economy Competitiveness in Terms of Global Crisis ProQuets, Economics of Agriculture SI-1 UDK: 502.131.1, 59, 78-85.

Brock, W. A., \& Taylor, M. S. (2005). The Green Solow Model. Journal of Economic Growth, 15 (2010), 127-153.

Brock, W. A., \& Taylor, M. S. (2015). The Green Solow Model. Journal Econ Growth, Springer, 15, 127-153. doi: 10.1007 / s10887-010-9051-0

Brunnermeier, S. and A. Levinson (2004), Examining the Evidence on Environmental Regulations and Industry Location," Journal of Environment \& Development, 13, 6-41.

Birdsall, Nancy; et al. (1993). Trade Policy and Industrial Pollution in Latin America: Where are The Pollution Haven?. The Journal of Environment \& Development. 2 (1):137-149.

Cato, M. S. (2009). Green Economics: An Introduction to Theory, Policy and Practice. London: Earthscan.

Cobb, C. W., \& Douglas, P. H. (1928). A Theory of Production. American Economic Review, 18: Suppl. (1928), 139-156.

Cole, M.A. and R.J.R. Elliott (2005), FDI and the Capital Intensity of 'Dirty' Sectors: A Missing Piece of the Pollution Haven Puzzle," Review of Development Economics, 9, 530-548.

M. A. Cole, R J.R. Elliott, "Determining the Trade-Environment Composition Effect: the Role of Capital, Labor and Environmental Regulations", Journal of Environmental Economics and Management 46: 363-383, 2003.

Dobson, A. (2000). Green Political Thought. Abingdon: Routledge.

Goulder, L. H. (2013). Market for Pollution Allowances: What are the (New) Lessons? Journal of Economic Perspectives, 291
(WInter 2013), 87-102.

Grossman, G. M., \& Krueger, A. B. (1991). Environmental impacts of a North American Free Trade Agreement. Working Paper 3914. Cambridge MA: National Bureau of Economic Research, NBER.

Harrod, R. F. (1939). An Essay in Dynamic Theory. The Economic Journal, Vol. 49, No. 193 (Mar. 1939), 14-33.

Jones, C. I., \& Romer, P. M. (2009). The New Kaldor Facts: Ideas, Institutions, Population, and Human

Capital. Paper presented at the the January 2009 annual meeting of the American Economic Association on "The Secrets of growth: What have we learned from research in the last 25 years?".

Karimi, S. (1995). Market Structure, Income Distribution and Poverty. Paper presented at the Upgrading Research Lecturer Kopertis Region X, August 3, 1995, Padang.

Karimi, S. (2012). Integration of Green Economy. Paper presented at the Workshop on Current Fiscal, 14 to 17 August 2012, the Fiscal and Financial Policy Board of the Ministry of Finance, Jakarta.

Kennet, M., \& Heinemann, V. (2006). Green Economics: setting the scene. Aims, context, and philosophical underpinning of the distinctive new solutions offered by Green Economics. Int. J. Green Economics, 1, Nos. 1/2, 68-102.

Keynes, J. M. (1936). A General Theory of Employment, interest and money. The ISN. Retrieved from www.isn.ithz.ch website:

Kellenberg, D.K. (2009), \An Empirical Investigation of the Pollution Haven Effect with Strategic Environment and Trade Policy," Journal of International Economics, 78, 242-255.

Lane, D. H. (2007). A Guide to Measures of Trade Openness and Policy: Indiana University South Bend.

Liddle, B. (2001): "Free trade and the environment-development system", Ecological Economics 39, 21 - 36.

Mathews, J. A. (2011). Naturalizing capitalism: The Next Great Transformation. Futures, Elsevier.

Park, J. (2013). The Evolution of Green Growth Policy: An Unwelcome Intrusion on Global Environmental Governance? Journal of East Asian Economic 
Integration, 17 \# 2 (June 2013), 207-241.

Ramsey, F. P. (1928). A Mathematical Theory of

Saving. The Economic Journal, 38152 (Dec., 1928), 543-559.

Saito, K., \& Yakita, A. (2008). Optimal Environmental Policy in Developing Economies. Association for Public Economic Theory, (Apr., 2008). Retrieved from

http://www.accessecon.com/pubs/PET08/ GeneralPDFPET08/PET08-08-00196S.pdf website:

Skousen, M. (2001). The Maestro "Modern Economics Theories" History of Economic Thought. Jakarta: Prenada Media.

Smith, A. (1776). An Inquiry into the Nature and Causes of the Wealth of Nations SM Soares (Ed.)

Soedomo, S. (2010). Green Economy: Approach Social, Cultural and Technology. Paper presented at the discussion Bappenas, 14 July 2010.

Solow, R. M. (1956). A Contribution to the Theory of Economic Growth. The Quarterly Journal of Economics, 70 \# 1 (of February, 1965), 65-94.

Stern, D. I. (2004). The Rise and Fall of the Environmental Kuznets Curve. World Development, 32 No. 8, 1419-1439.

Talberth, J., \& Boharas, A. K. (2006). Economic openness and green GDP. Ecological Economic, 58 (4), 743-758.

Tucker, M. E., \& Gring, J. A. (2001). Introduction The emerging alliance of World Religion and ecology. ProQuets, Agriculture journal, 130 (4), 1-22.

Taylor, M. S. (2004), "Unbundling the Pollution Haven Hypothesis", Advances in Economic Analysis and Policy, Vol. 4 (2), article 8.

Tasri, evi susanti, 2015, Studi empiris pertumbuhan ekonomi hijau dan polusi, Draft disertasi, pasca sarjana universitas andalas, padang.

Wang, X. (2011). Green GDP and openess: Evidence from Chine Provincial Comparable Green GDP. Journal of Cambridge Studies, 6 \# 1 (March, 2011).

winter, J. G. (1999). Bigger, Badder, but not better a new breed economist exposes the myth of unlimited growth. 20,4,4 ProQuets, biology journal, 32-36.

Winters, LA, McCulloch, N., \& McKay, A. (2004). Trade liberalization and poverty: The evidence so far. Journal of Economic Literature, XLII (2004), 72-115.

Yandle, B., Vijayaraghavan, M., \& Bhattarai, M. (2002). The Environmental Kuznets Curve: A Primer. PERC Research Study, 02-1 (May, 2002). 